\title{
Biofabrication of gold nanoparticles by Shewanella species
}

\author{
Jhe-Wei Wu and I-Son $\mathrm{Ng}^{*}$ (])
}

\begin{abstract}
Background: Shewanella oneidensis MR-1 (MR-1) and Shewanella xiamenensis BC01 (SXM) are facultative anaerobic bacteria that exhibit outstanding performance in the dissimilatory reduction of metal ions. Shewanella species have been reported to produce metal nanoparticles, but the mechanism and optimization are still not extensively studied and clearly understood. Herein, the effects of $\mathrm{pH}$, biomass, gold ion concentration, and photoinduction are evaluated to optimize gold nanoparticle (Au@NP) production by Shewanella.

Results: The highest amount of Au@NPs produced by SXM and MR-1 were 108 and 62 ppm, respectively, at pH 5 when $2.4 \mathrm{~g} / \mathrm{L}$ biomass was immersed in $300 \mathrm{ppm}$ gold ions and $50 \mathrm{mM}$ lactate under a light intensity of $100 \mathrm{\mu mol} /$ $\mathrm{m}^{2} / \mathrm{s}$. By scanning election microscopy and zeta potential analysis, the proposed mechanism of Au@NP formation was that Shewanella used lactate as electron donors for the Mtr pathway, stimulated by photosensitive proteins resulting in the nucleation of NPs on the cell membrane. Besides, the resting cells retained the ability for biofabrication of nanoparticles for nearly 25 days.

Conclusions: The optimal conditions evaluated for Au@NPs production by Shewanella were biomass, pH, ions concentration, and photoinduction. To the best of our knowledge, this is the first attempt to explore a two-step mechanism for Au@NPs formation in Shewanella. First, the $\mathrm{HAuCl}_{4}$ solution reacted with sodium lactate to form metallic gold ions. Second, the metallic gold ions were adsorbed onto the outer membrane of cell, and the formation of Au@NPs at the surface was triggered. Shewanella-based Au@NPs production could be a potential ecofriendly solution for the recovery of Au ions from secondary resources like industrial waste.
\end{abstract}

Keywords: Shewanella, Gold nanoparticle, Resting cell, Optimization, Photoinduction

\section{Background}

Because of global modernization and industrialization, pollution caused by the release of heavy metals into the environment has become a critical issue, and thus concerns surrounding the recovery of such heavy metals have been rising (Dodson et al. 2015). Among all metals commonly seen in wastes, gold is a noble metal and can be used in luxury jewelry, electronics, and medical applications because of its unique physical and chemical properties such as high biocompatibility and long-term stability (Ramesh et al. 2008; Spitzer and Bertazzoli 2004). Gold ions fabricated in nanoscale (gold nanoparticles or $\mathrm{Au} @$

\footnotetext{
*Correspondence: yswu@mail.ncku.edu.tw

Department of Chemical Engineering, National Cheng Kung University, Tainan 70101, Taiwan
}

NPs) with shape-dependent and optoelectronic properties have broadly applicable physiochemical characteristics and biological functions, and are thus of great interest to scientists (Klaus et al. 2001; Shedbalkar et al. 2014; Suresh et al. 2011).

Many traditional methods of gold recovery, such as cyanide leaching, precipitation and filtration, and electrochemical treatments, have been reported (Mata et al. 2009). However, these methods are challenged by restricted selectivity and large amounts of toxic chemicals involved in the process resulting in secondary pollution ( $\mathrm{He}$ et al. 2015). Compared with traditional methods, biological methods have great appeal because of their simplicity, elimination of toxic chemicals (Mishra et al. 2014), and capability of controlling nanoparticle size (Bai et al. 2009; Sathishkumar et al. 2010a). Over the 
last decade, adsorption and reduction of heavy metals by microorganisms including bacteria, yeast, and fungi have been reported (Farooq et al. 2010; Lo et al. 2014; Tan et al. 2017). The biofabrication of nanoparticles with optimal conditions, such as $\mathrm{pH}$, incubation time, and metal ion concentration (Narayanan and Sakthivel 2010) also showed high potential in commercial applications and large-scale production.

Shewanella species, which are dissimilatory metalreducing bacteria widely distributed in sediment or seawater, grow optimally between 25 and $40{ }^{\circ} \mathrm{C}$ and can reduce metal ions via a special electron pathway called the Mtr pathway (Fredrickson et al. 2008; Shi et al. 2012; Wang et al. 2017). Shewanella oneidensis MR-1, isolated from Oneida Lake, New York (Myers and Nealson 1988), has been reported to reduce $\mathrm{Au}^{3+}$ into discrete sphericalAu@NPs that are well dispersed with homogeneous sizes. The nanoparticle sizes of gold produced by MR-1 were in the range of $2-50 \mathrm{~nm}$ and had high potential for use in biomaterials (Suresh et al. 2011). In the MR-1 strain, the outer membrane c-type cytochromes, MtrC and OmcA, were considered as important proteins for metal reduction (Wu et al. 2013a). However, the MR-1 wild type and its mutants $o m c A$ and $m t r C$ were still capable of reducing $\mathrm{Au}^{3+}$ into Au@NPs (Wu et al. 2013b), while the particle size of the extracellular nanoparticles were decreased $m t r C$ and $o m c A$ mutants (Ng et al. 2013). On the other hand, Shewanella xiamenensis, which is isolated from coastal sediment collected off Xiamen, China, is a close-related strain to $S$. oneidensis based on phylogenetic tree analysis by $16 \mathrm{~S}$ rRNA and gyrase gene (Huang et al. 2010). It has also been reported to reduce mediators from the medium to nanoparticles (Ng et al. 2015a) and also showed resistance to different kinds of metal ions (Ng et al. 2015b).

The mechanism and conditional optimization of Au@ NP production by Shewanella have never been reported. The aim of this study is to explore the mechanism and to accomplish optimization by determining the effects of $\mathrm{pH}$, biomass, and gold concentration on Au@NP production by $S$. oneidensis MR-1 and S. xiamenensis BC01 (SXM). Finally, the resting cell activity on the biofabrication of Au@NPs and silver nanoparticles (Ag@NPs) is also examined.

\section{Methods}

\section{Chemicals}

For the reduction of gold and silver ions, chloroauric acid $\left(\mathrm{HAuCl}_{4} \cdot 3 \mathrm{H}_{2} \mathrm{O}\right)$ was purchased from Alfa Aesar, silver nitrate $\left(\mathrm{AgNO}_{3}\right)$ was purchased from Sigma (209139), and sodium lactate $(50 \% \mathrm{w} / \mathrm{w})$ was purchased from Showa (G1510E). For scanning electron microscopy, formvar solution was purchased from Sigma (09823), and tert-butanol was purchased from Shimakyu Chemical Co. Ltd.

\section{Bacteria culture}

Both S. xiamenensis BC01 (SXM) and S. oneidensis MR-1 were grown in Luria-Bertani broth containing yeast extract $(5 \mathrm{~g} / \mathrm{L})$, sodium chloride $(10 \mathrm{~g} / \mathrm{L})$, and tryptone $(10 \mathrm{~g} / \mathrm{L})$. The cells were maintained at $4{ }^{\circ} \mathrm{C}$ on $\mathrm{LB}$ plates, and a single colony was inoculated into $2 \mathrm{~mL}$ of $\mathrm{LB}$ medium and cultured at $30^{\circ} \mathrm{C}$ and $150 \mathrm{rpm}$ for $12 \mathrm{~h}$ for preculture. Then, $1 \%(\mathrm{v} / \mathrm{v})$ of the precultured cells was transferred into a $50-\mathrm{mL}$ flask containing $10 \mathrm{~mL}$ of $\mathrm{LB}$ medium and grown aerobically at $30{ }^{\circ} \mathrm{C}$ and $150 \mathrm{rpm}$ for another $12 \mathrm{~h}$.

\section{Biofabrication and characterization of nanoparticles}

Cells were collected by centrifugation at $8000 \times g$ for $5 \mathrm{~min}$ and washed twice with $0.5 \mathrm{~mL}$ of distilled water to obtain a final biomass concentration of $2.4 \mathrm{~g} / \mathrm{L}$. The precipitate was resuspend in $50 \mathrm{mM}$ sodium lactate as the electron donor with $0.5 \mathrm{~mL}$ of $300 \mathrm{ppm} \mathrm{Au}^{3+}$ or $100 \mathrm{ppm}$ $\mathrm{Ag}^{+}$solution. The samples were incubated at room temperature (approximately $30{ }^{\circ} \mathrm{C}$ ) with a light intensity of $100 \mu \mathrm{mol} / \mathrm{m}^{2} / \mathrm{s}$ for $24 \mathrm{~h}$.

\section{UV-vis spectroscopy analysis of nanoparticle formation}

The nanoparticles were analyzed using UV-vis spectroscopy (Molecular Devices, SpectraMax 340 PC $^{384}$, USA) to measure the surface plasmon resonance at $530 \mathrm{~nm}$ for Au@NPs and 410 nm for Ag@NPs. The color of the sample changed from pale yellow to purple to indicate the formation of Au@NPs (Kumar et al. 2008). For Ag@NPs, the color changed from pale yellow to orange.

\section{Scanning electron microscopy (SEM)}

The samples were fixed in $2.5 \%(\mathrm{w} / \mathrm{v})$ glutaraldehyde for $2 \mathrm{~h}$ and washed three times with phosphate buffer $(0.1 \mathrm{M}$, $\mathrm{pH}$ 7.4). The sample $(100 \mu \mathrm{L})$ was carefully dropped onto a formvar-coated silicon chip for $1 \mathrm{~h}$ and washed three times with phosphate buffer. The cells were dehydrated in a series of ethanol washes with increasing ethanol concentration (30,50,70, and $100 \%)$. After three final washes in $100 \%$ ethanol, the samples were immersed in tert-butanol and dried by lyophilization (KINGMECH, FD3-12P, Taiwan) for $0.5 \mathrm{~h}$. Dehydrated samples were analyzed using SEM (JEOL JSM-6700F, Japan).

\section{Inductively coupled plasma-optical emission spectrometry (ICP-OES)}

Cells were centrifuged at 10,000 rpm for $10 \mathrm{~min}$, and the supernatant was filtered using a $0.22-\mu \mathrm{m}$ filter (Millipore, USA). $\mathrm{Au}^{3+}$ concentration was measured using ICP-OES (ULTIMA 2000, Japan). A standard solution 
containing $1000 \mathrm{ppm} \mathrm{Au}^{3+}$ (High-Purity Standards, USA) or $200 \mathrm{ppm} \mathrm{Ag}^{+}$was used as the starting solution and diluted in the range from 0 to $100 \mathrm{ppm}$ for ICP-OES analysis.

\section{Zeta potential}

Samples for zeta potential measurement were prepared as follows. Cells were added into $1 \mathrm{~mL}$ of distilled water in Falcon tubes with a final biomass concentration of $1.2 \mathrm{~g} / \mathrm{L}$. Different samples with a volume of $750 \mu \mathrm{L}$ were introduced into cuvettes, and the zeta potential was measured (Malvern, Zetasizer Nano ZS, UK).

\section{Preparation of resting cells}

Strains were grown aerobically at $30{ }^{\circ} \mathrm{C}$ and $150 \mathrm{rpm}$ in $250-\mathrm{mL}$ flasks containing $50 \mathrm{~mL}$ of Luria-Bertani medium for $12 \mathrm{~h}$. Cells were collected by centrifugation at $8000 \times g$ for $10 \mathrm{~min}$ and washed twice by distilled water. The precipitate was resuspended by $1 \mathrm{~mL}$ of distilled water, and the sample was quickly frozen in liquid nitrogen. The resting cells were generated by overnight lyophilization into a powder and stored at $-20{ }^{\circ} \mathrm{C}$ for long-term storage.

\section{Results and discussion \\ Effect of pH}

There have been reports on the biosynthesis of metal nanoparticles using Shewanella species (Ng et al. 2013; Suresh et al. 2011), but the physical factors for optimization have rarely been reported. Therefore, it is critical and meaningful to explore the optimal conditions of Au@NP biofabrication by SXM and MR-1. By adjusting the $\mathrm{pH}$ to $3,4,5$, and 6 , Shewanella produced different quantities of Au@NPs. It was obvious that SXM produced more Au@NPs than MR-1 did, as shown in Table 1. SXM produced 116 and 108 ppm Au@NPs at $\mathrm{pH} 4$ and 5, respectively, while MR-1 only produced 62 ppmAu@NPs at pH 5. The production of Au@NPs by both strains decreased dramatically at $\mathrm{pH} 6$. The value of $\mathrm{pH}$ was considered an important factor for gold reduction and nanoparticle formation (Mishra et al. 2012), as the different $\mathrm{pH}$ values affect the zeta potential, thus influenced the electric properties on the cell surface to form nanoparticles. The effect of $\mathrm{pH}$ was consistent with the results of $S$. haliotis, which has an optimal $\mathrm{pH}$ of 5 (Zhu et al. 2016). In addition, neutral conditions were not appropriate for Shewanella for the production of Au@NPs.

\section{Effect of biomass and concentration of gold ions}

As shown in Fig. 1a, the dark purple colors indicated Au@NPs formation by both Shewanella. As shown in Fig. 1b, the gold ions were adsorbed onto the cell surface
Table 1 The effect of pH on Shewanella at biomass of a $0.6 \mathrm{~g} / \mathrm{L}$ to produce Au@NP with $300 \mathrm{ppm} \mathrm{Au}{ }^{3+}$ after $24 \mathrm{~h}$

\begin{tabular}{lcc}
\hline $\mathrm{pH}$ & Au@NPs (ppm) & \\
\cline { 2 - 3 } & S. xiamenensis BC01 & S. oneidensis MR-1 \\
\hline 3 & $17.0 \pm 3.5$ & $33.1 \pm 4.2$ \\
4 & $116.7 \pm 27.5$ & $44.7 \pm 7.9$ \\
5 & $108.0 \pm 9.2$ & $62.0 \pm 9.1$ \\
6 & $45.9 \pm 4.6$ & $1.6 \pm 4.7$ \\
\hline
\end{tabular}
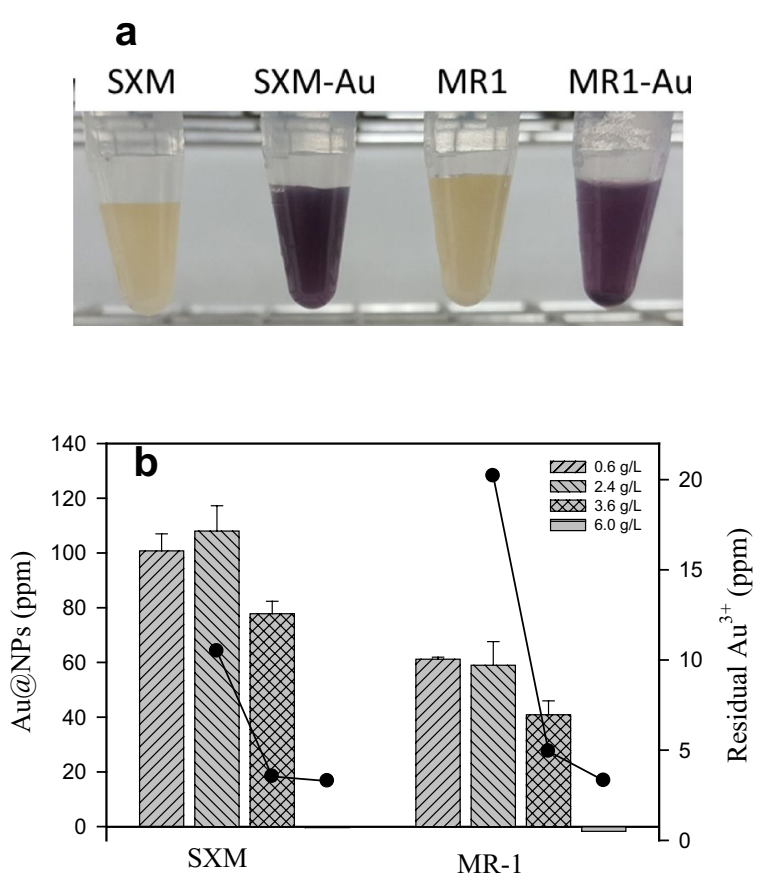

Fig. 1 a The image of Au@NP production by SXM and MR-1. b The effect of Shewanella biomass on Au@NP formation when immersed in 300 ppm $\mathrm{Au}^{3+}$ after 24 h. Left axis, bar: Au@NPs. Right axis, dot: residual $\mathrm{Au}^{3+}$ concentration

when the biomass increased, and the concentration of gold dropped from 300 to $3 \mathrm{ppm}$ with $6 \mathrm{~g} / \mathrm{L}$ biomass. As a result, the residual concentration of Au decreased significantly when $3.6 \mathrm{~g} / \mathrm{L}$ biomass was used, and residual $\mathrm{Au}^{3+}$ was relatively low (i.e., $<5 \mathrm{ppm}$ ) in both strains. However, the quantity of Au@NPs did not increase when the biomass increased from 2.4 to $6.0 \mathrm{~g} / \mathrm{L}$ (Fig. 1b, bar graph). Maximal amounts of Au@NPs were generated at 2.4 $\mathrm{g} / \mathrm{L}$ biomass (108 and 58.9 ppm for SXM and MR-1, respectively). The morphology of Shewanella in different biomass concentrations and the amounts of Au@ NPs formed could be further analyzed by SEM as shown in Fig. 2. It was evident that Au@NPs were fabricated on the outer membrane of cells at 2.4 and $3.6 \mathrm{~g} / \mathrm{L}$ biomass. When the biomass increased to $6.0 \mathrm{~g} / \mathrm{L}$, the cell 


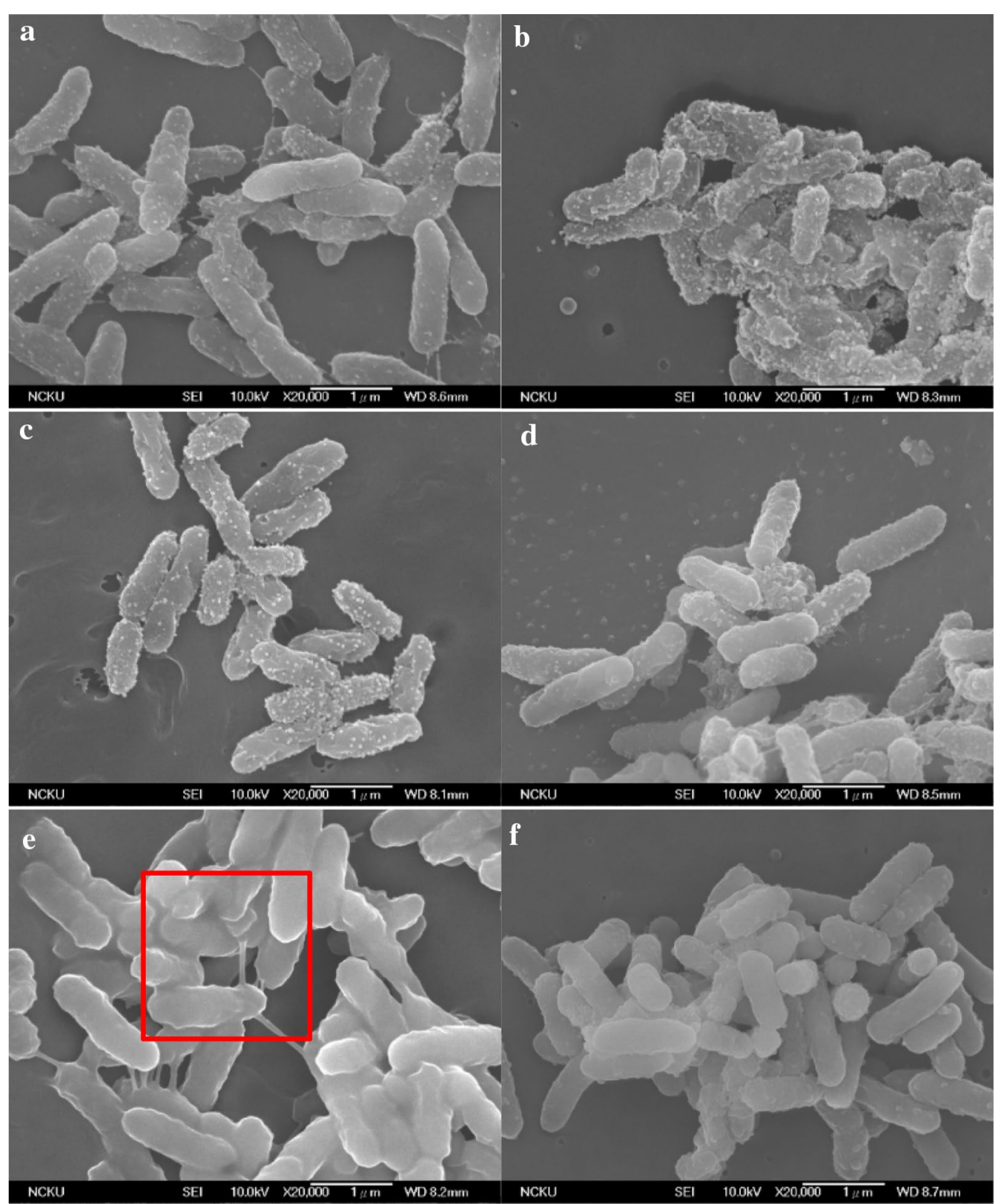

Fig. 2 SEM analysis of SXM at biomass of a $0.6 \mathrm{~g} / \mathrm{L}, \mathbf{c} 2.4 \mathrm{~g} / \mathrm{L}$, and $\mathbf{e} 6.0 \mathrm{~g} / \mathrm{L}$, and of MR-1 at $\mathbf{b} 0.6 \mathrm{~g} / \mathrm{L}, \mathbf{d} 2.4 \mathrm{~g} / \mathrm{L}$, and $\mathbf{f} 6.0 \mathrm{~g} / \mathrm{L}$ when immersed in $300 \mathrm{ppm} \mathrm{Au}^{3+}$ for $24 \mathrm{~h}$

membrane became thicker and sticky (shown in red rectangle in Fig. 2e). Although gold ions would adsorb on the cell surface, it was not beneficial to generate Au@ NPs through nucleation layer by layer when biomass increased up to $3.6 \mathrm{~g} / \mathrm{L}$.

The effect of gold concentration on Au@NP formation was tested within the range of $10-300 \mathrm{ppm} \mathrm{Au}^{3+}$. As shown in Table 2, no Au@NPs were produced at 0.6 and $2.4 \mathrm{~g} / \mathrm{L}$ biomass when the concentration of gold ions was $50 \mathrm{ppm}$. Even when the concentration of gold ions increased to $100 \mathrm{ppm}$, only approximately $5 \mathrm{ppm}$ Au@NPs were generated in (i.e., 5\% conversion). When the gold concentration was greater than $100 \mathrm{ppm}$, Shewanella produced Au@NPs that proportionally increased when the $\mathrm{Au}^{3+}$ increased from 100 to $300 \mathrm{ppm}$. As shown in Table 2, it was obvious that SXM produced more Au@NPs than MR-1 with the increasing amount of $\mathrm{Au}^{3+}$. Moreover, the threshold of gold concentration for 
Table 2 The effect of gold ion concentration on Shewanella in Au@NP formation after $24 \mathrm{~h}$

\begin{tabular}{|c|c|c|c|c|}
\hline \multirow[t]{3}{*}{$\mathrm{Au}^{3+}(\mathrm{ppm})$} & \multicolumn{4}{|c|}{ Au@NPs (ppm) } \\
\hline & \multicolumn{2}{|c|}{ S. xiamenensis BC01 } & \multicolumn{2}{|c|}{ S. oneidensis MR-1 } \\
\hline & $0.6 \mathrm{~g} / \mathrm{L}$ & $2.4 \mathrm{~g} / \mathrm{L}$ & $0.6 \mathrm{~g} / \mathrm{L}$ & $2.4 \mathrm{~g} / \mathrm{L}$ \\
\hline 50 & $\mathrm{Nd}$ & $\mathrm{Nd}$ & $\mathrm{Nd}$ & $\mathrm{Nd}$ \\
\hline 100 & 5.3 & $\mathrm{Nd}$ & 4.9 & $\mathrm{Nd}$ \\
\hline 200 & 33.9 & 48.2 & 31.9 & 12.8 \\
\hline 300 & 100.8 & 108.0 & 61.2 & 59.0 \\
\hline
\end{tabular}

$N d$ not detected

Shewanella to produce Au@NPs is reported here for the first time.

A comparison of Au@NP formation using other microbes is shown in Table 3. The optimal biomasses of S. haliotis, Aspergillus oryzae var. viridis, and Sargassum sp. were $5.3,10$, and $5 \mathrm{~g} / \mathrm{L}$, respectively (Binupriya et al. 2010; Sathishkumar et al. 2010b; Zhu et al. 2016). Herein, the optimal biomass of SXM and MR-1 was $2.4 \mathrm{~g} / \mathrm{L}$, which was much lower than those of the other bacteria. Moreover, the formation of Au@NPs occurred within $4 \mathrm{~h}$, which was much faster than those shown in previous reports. The absorbance intensities of SXM and MR-1, corresponding to the amounts of Au@NPs, were significantly higher than those of the other species. Because of the lower biomass used, higher reaction rates, and higher productivity, MR-1 and SXM have great advantages in gold reduction to nanoparticles.

\section{Photo effect on Au@NP formation}

As shown in Fig. 3a, the color of the solution changed rapidly within $4 \mathrm{~h}$ from pale yellow to purple when exposed to light at an intensity of $100 \mu \mathrm{mol}$ photons $/ \mathrm{m}^{2} / \mathrm{s}$, indicating that the reaction rate of Shewanella in the presence of light was far greater than that of the solution in darkness. We also compared the wild type Shewanella (i.e., MR-1
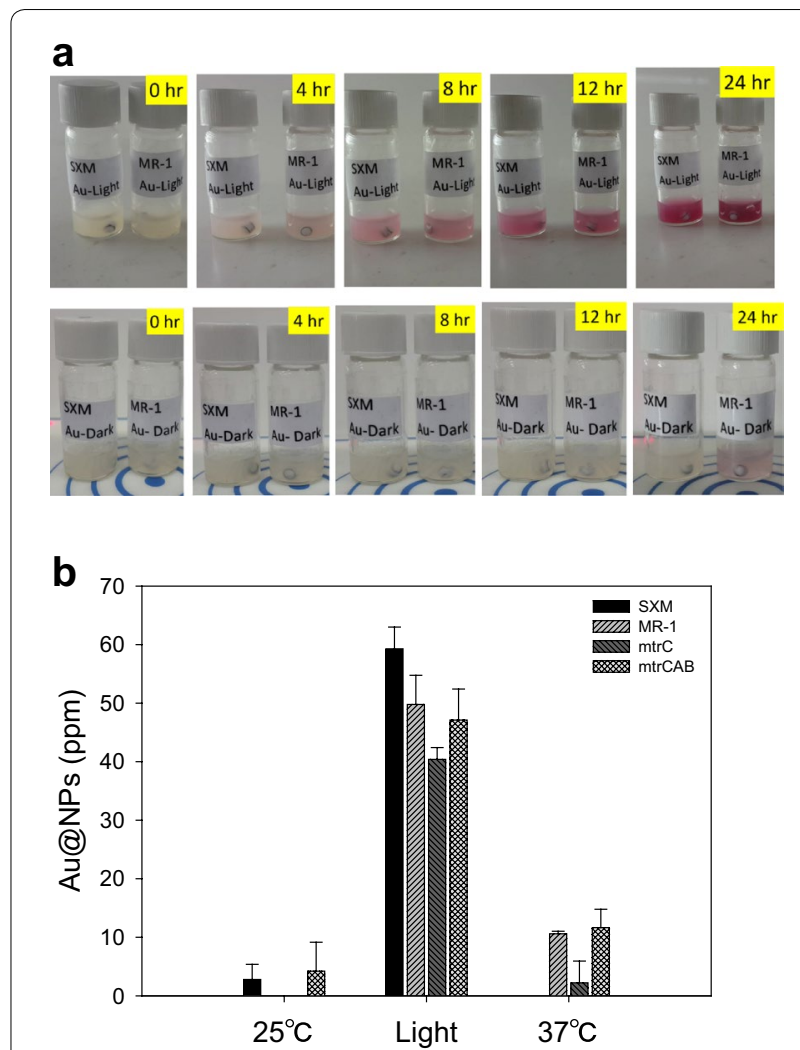

Fig. 3 Effect of light on Shewanella in Au@NP formation when

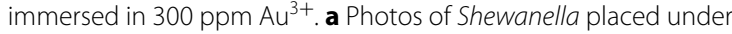
light (top) and in the dark (bottom) within 24 h. b Amount of Au@NPs produced by Shewanella at $25^{\circ} \mathrm{C}$, light effect, and $37^{\circ} \mathrm{C}$ for $24 \mathrm{~h}$

and SXM) and genetically modified strains (i.e., cells harboring $m t r C$ and $m t r C A B$ genes). As shown in Fig. 3a, cells placed in light produced more Au@NPs in the time series from 0 to $24 \mathrm{~h}$. Temperature was not a critical factor for Au@NP formation as shown in Fig. 3b. Very low levels of Au@NPs were produced at 25 and $37{ }^{\circ} \mathrm{C}$ without light induction. In addition, the MR-1 strains harboring

Table 3 Comparison of different strains in biofabrication of Au@NPs

\begin{tabular}{|c|c|c|c|c|c|c|c|}
\hline Microorganisms & $\mathrm{pH}$ & $\operatorname{Temp}\left({ }^{\circ} \mathrm{C}\right)$ & Biomass (g/L) & $\begin{array}{l}\text { Light density ( } \mu \mathrm{mol} \\
\text { photons } / \mathrm{m}^{2} / \mathrm{s} \text { ) }\end{array}$ & $\begin{array}{l}\text { Color change time } \\
\text { (h) }\end{array}$ & $\begin{array}{l}\text { Absorbance inten- } \\
\text { sity after } 24 \mathrm{~h}\end{array}$ & References \\
\hline $\begin{array}{l}\text { Shewanella xiam- } \\
\text { emensis BC01 }\end{array}$ & 5 & RT & 2.4 & 100 & 4 & 2.5 & This study \\
\hline $\begin{array}{l}\text { Shewanella oneidensis } \\
\text { MR-1 }\end{array}$ & 5 & RT & 2.4 & 100 & 4 & 1.7 & This study \\
\hline Shewanella haliotis & 5 & 30 & 5.3 & $x$ & 12 & 1.0 & (Zhu et al. 2016) \\
\hline $\begin{array}{l}\text { Aspergillus oryzae var. } \\
\text { viridis }\end{array}$ & 7 & 25 & 10 & $x$ & 10 & 0.4 & (Binupriya et al. 2010) \\
\hline Sargassum sp. & 8 & RT & 5 & $x$ & 0.5 & 0.05 & $\begin{array}{l}\text { (Sathishkumar et al. } \\
\text { 2010b) }\end{array}$ \\
\hline
\end{tabular}

$R T$ room temperature 
$m t r C$ or $m t r C A B$ genes showed the same levels of nanoparticle production under light induction, which implies that the Mtr pathway proteins are not stimulated by light. It is known that cyanobacteria possess light-sensitive phytochromes to control photosynthesis, phototaxis, and production of pigments (Schmitz et al. 2000; Yeh et al. 1997). A phytochrome is a two-component system, with a membrane-bound sensor protein and an intracellular response regulator protein, which function in sequence in response to an extracellular signal. An $E$. coli strain has been artificially engineered to respond to light by replacing the osmolarity sensing domain EnvZ to a photosensing domain from the cyanobacteria in the native EnvZ-OmpR two-component system (Levskaya et al. 2005). The engineered $E$. coli strain was photosensitive and could turn on or shut down the expression of the reporter gene according to illumination. Therefore, we hypothesize that photoinduction in Shewanella which caused the formation of Au@NPs could be regulated by a two-component protein system. In our experiments, the formation of Au@NPs was significantly increased by photoinduction. From the genomic database of MR-1 (Accession Number NC004347), a putative two-component system with a photoreactivation-associated protein (PhrA) and photolyase (PhrB) could be involved in sensing of light. These light-sensitive proteins may be the key factor in stimulating the formation of Au@NPs. The search for key proteins by genetic method, i.e., knock-out $p h r \mathrm{~A}$ and $p h r \mathrm{~B}$, is an inevitable further research motive for this study. In the past, the $S$. algae strain BRY was found to reduce $\mathrm{Au}^{3+}$ to $\mathrm{Au}$ using hydrogen as the electron donor (Kashefi et al. 2001). Alternatively, Shewanella species have been considered for the bioremediation of different kinds of metals ions or for use in microbial fuel cells (Chen et al. 2015; Liu and Logan 2004; Xu et al. 2006). This is the first attempt to discover the effects of temperature and light on the formation of Au@NPs.

\section{The proposed mechanism of Au@NP formation}

The zeta potential analysis is shown in Fig. 4a. Significant differences in zeta potential were observed at biomasses of 2.4 and $1.2 \mathrm{~g} / \mathrm{L}$ for SXM and MR-1, respectively. The difference in zeta potential gradually decreased when the biomass was greater than $3.6 \mathrm{~g} / \mathrm{L}$. At $6.0 \mathrm{~g} / \mathrm{L}$ biomass, no difference in zeta potential was detected. This shows the disadvantage of high biomass (6.0 g/L) for Au@NP formation. Recent research shows that the changes in zeta potential of MR-1 not only reflect on the production of Au@NPs, but also the formation of biofilm (Ishiki et al. 2017). Therefore, with higher cell density, increased biofilm formation could affect the nucleation of gold atoms to NPs. On the other hand, the ICP-OES analysis of residual ion concentration after immersion of SXM or
MR-1 in $300 \mathrm{ppm}$ gold solution or $100 \mathrm{ppm}$ silver solution with biomass concentrations ranging from 2.4 to $6 \mathrm{~g} / \mathrm{L}$, we found that only 20.8 to $3.29 \mathrm{ppm}$ of residual gold ions or 2.26 to $0.81 \mathrm{ppm}$ of residual silver ions were present for both SXM and MR-1 at lower or higher biomass (Table 4). Our hypothesis for the mechanism of Au@NPs formation by Shewanella is shown in Fig. 4b.
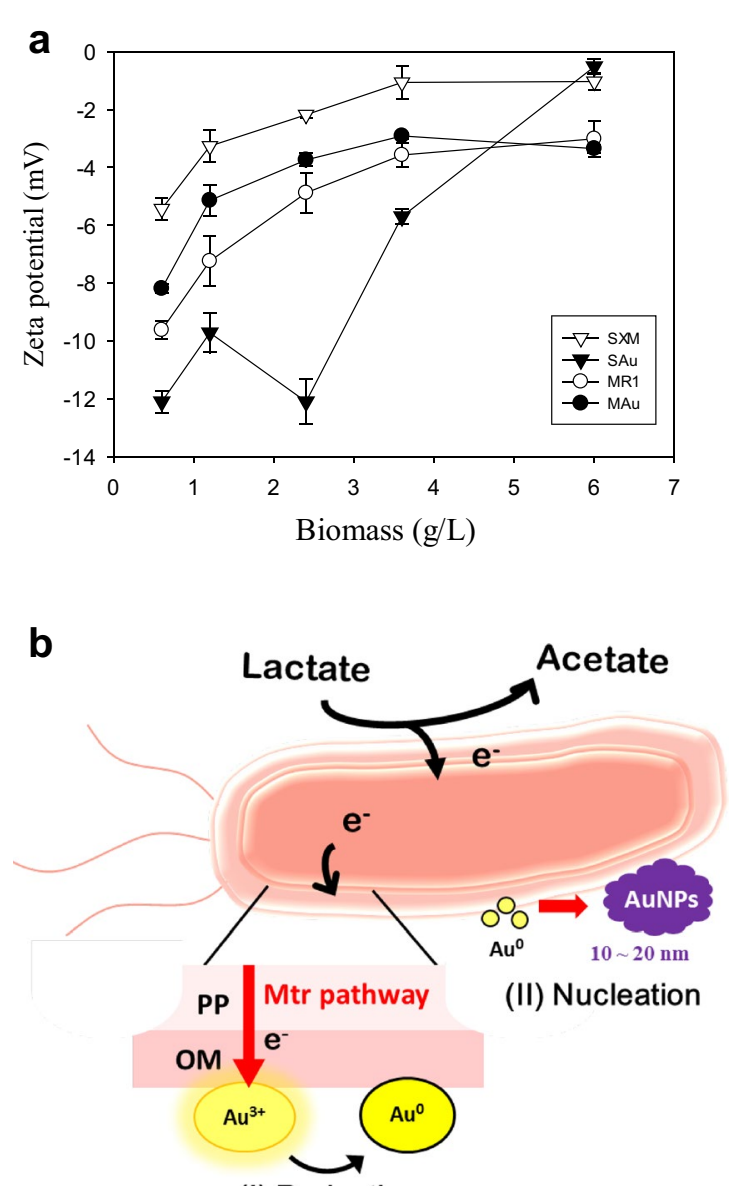

(I) Reduction

Fig. 4 a Zeta potential analysis of S. oneidensis MR-1 and S. xiamenensis BC01 before and after the formation of Au@NPs. b Proposed mechanism of Au@NP production using Shewanella

Table 4 ICP-OES analysis of residual ion concentration after immersion in $\mathrm{Au}^{3+}$ or $\mathrm{Ag}^{+}$by SXM or MR-1 at different biomasses for $24 \mathrm{~h}$

\begin{tabular}{llll}
\hline Metal conc. & Biomass conc. (g/L) & \multicolumn{2}{l}{ Final conc. (ppm) } \\
\cline { 3 - 4 } & & SXM & MR-1 \\
\hline $300 \mathrm{ppm} \mathrm{Au}^{3+}$ & 2.4 & $11.9 \pm 0.12$ & $20.8 \pm 0.11$ \\
$300 \mathrm{ppm} \mathrm{Au}^{3+}$ & 6.0 & $3.29 \pm 0.08$ & $3.31 \pm 0.13$ \\
$100 \mathrm{ppm} \mathrm{Ag}^{+}$ & 2.4 & $2.21 \pm 0.02$ & $2.26 \pm 0.05$ \\
$100 \mathrm{ppm} \mathrm{Ag}^{+}$ & 6.0 & $0.81 \pm 0.03$ & $1.17 \pm 0.04$ \\
\hline
\end{tabular}


Sodium lactate acted as the electron donor at a final concentration of $50 \mathrm{mM}$. Then, Shewanella adsorbed the gold ions, and nucleation was triggered on the cell membrane layer by layer, while higher biomass blocked the nucleation. Because of the distinct electron pathway of Shewanella, gold ions were reduced on the outer membrane of the cells, further accomplishing the process of nanoparticle fabrication and resulted in different zeta potentials on cell.

In the formation of Au@NPs, the first step is the reduction of gold ions to metallic gold atoms. This process is supposed to be the common reduction, where the electron donor lactate goes through the Mtr pathway (i.e., $m t r \mathrm{~A}, m t r \mathrm{~B}, m t r \mathrm{C}$, and $o m c \mathrm{~A}$ ) and excess electrons enter the cytoplasmic membrane-anchored tetrahaem c-type cytochrome CymA to accomplish the reduction. The importance of proteins in Mtr pathway and cytochrome c-type has also been demonstrated in DMSO or dinitrotoluene reduction (Coursolle and Gralnick 2010; Liu et al. 2017). Moreover, as Au@NPs formation by Shewanella was photoinduced, there is the supposed involvement of a prospective two-component system [photoreactivationassociated protein $(\mathrm{PhrA})$ and photolyase $(\mathrm{PhrB})]$ which was activated by light energy to drive electron transfer and accelerate the reduction (Ng et al. 2000; Sancar 2003). Second, the nucleation of gold atom as a nanoparticle on cell surface should be a "layer by layer" processing, obeying thermodynamics and kinetic behavior. Thus, with higher cell density, the thicker biofilm formed would be a drawback for nanoparticles formation.

\section{The activity of resting cells}

Apart from the fresh cells, resting cells were also used for Au@NP formation. Resting SXM and MR-1 cells were prepared based on the method described in "Preparation of resting cells". They were stored at $-20{ }^{\circ} \mathrm{C}$ for longterm conservation as shown in Fig. 5a. The ability of resting cells to produce Au@NPs was analyzed after 1, 15, 20, and 25 days. The resting cells had nearly $60 \%$ capability for Au@NPs production after 25 days (Fig. 5b), the variations in the activity could be attributed to the nonuniform cell powder. The resting cells were preferable as they could be used at any time without several repeated steps. Although there was a report showing that resting $S$. algae cells generated reduced amounts of platinum nanoparticles (Konishi et al. 2007), this is also the first attempt in showing that resting Shewanella cells possess long-term stability for the fabrication of Au@NPs.

\section{The selectivity of gold and silver ions by Shewanella}

The ability for Ag@NPs formation by SXM and MR-1 was shown in the blue line shown in Fig. 6. The Ag@NPs exhibited surface plasmon resonance at $410 \mathrm{~nm}$. In order to confirm the selectivity of $\mathrm{Au}^{3+}$ and $\mathrm{Ag}^{+}$ions by Shewanella, both strains were examined in a solution containing $100 \mathrm{ppm} \mathrm{Au}^{3+}$ and $100 \mathrm{ppm}^{+} \mathrm{Ag}^{+}$ions (red line in Fig. 6) or $250 \mathrm{ppm} \mathrm{Au}{ }^{3+}$ and $100 \mathrm{ppm} \mathrm{Ag}^{+}$ions (green line in Fig. 6) for $24 \mathrm{~h}$. The results showed that both SXM (Fig. 6a) and MR-1 (Fig. 6b) reduced silver ions at the same concentration, and reduced $\mathrm{Au}^{3+}$ when immersed in $250 \mathrm{ppm} \mathrm{Au}^{3+}$ and $100 \mathrm{ppm} \mathrm{Ag}^{+}$ions. The selectivity can also be controlled by the concentration of ions inside the system.

\section{Conclusions}

Shewanella xiamenensis $\mathrm{BC} 01$ and $\mathrm{MR}-1$ reduced $\mathrm{Au}^{3+}$ to Au@NPs, which were localized on the surface. By measuring the optimal condition, the highest amounts
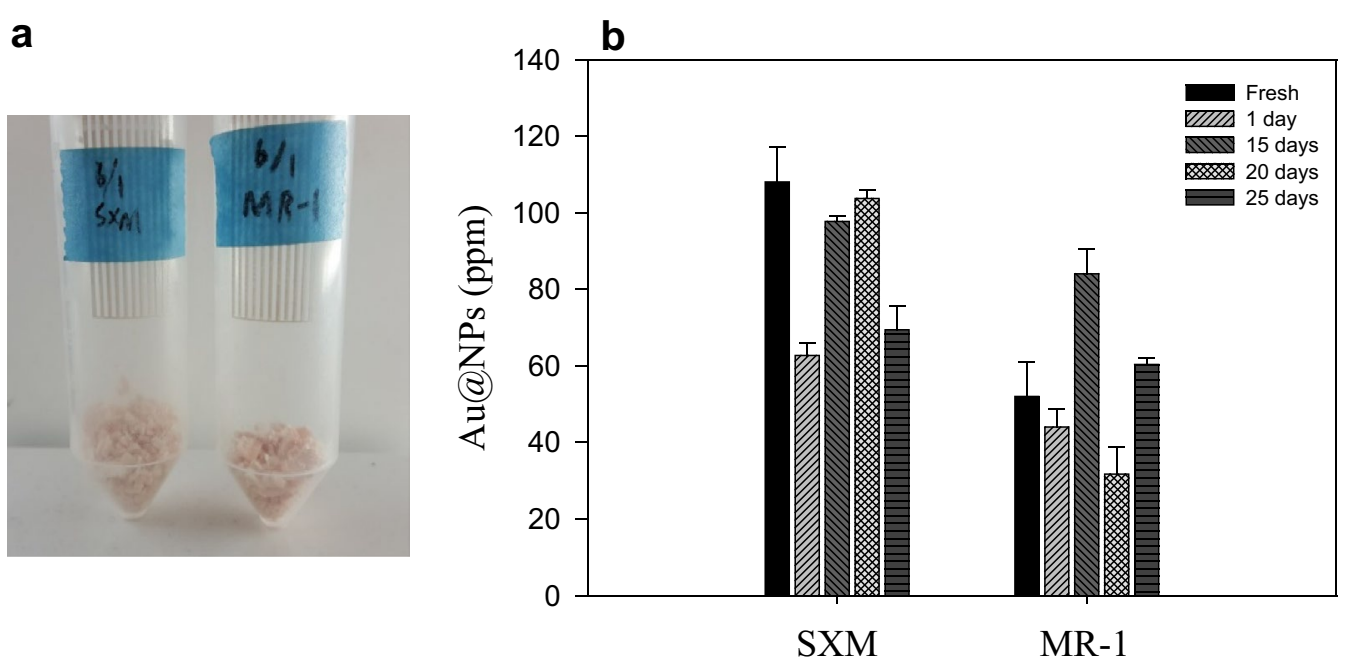

Fig. 5 a Resting Shewanella cells. b Biofabrication of Au@NPs by resting cells after 1, 15, 20, and 25 days 

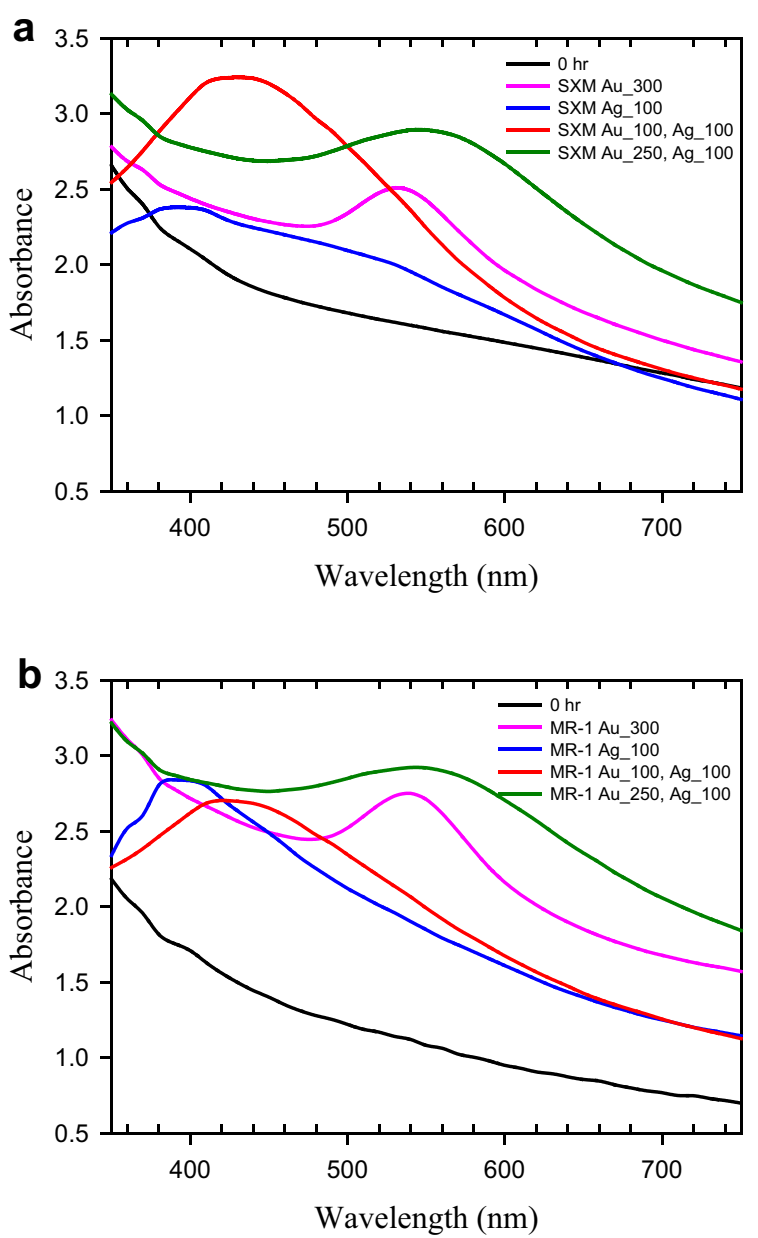

Fig. 6 Selectivity of a SXM and $\mathbf{b}$ MR-1 immersed in only 300 ppm $\mathrm{Au}^{3+}$ (pink), only $100 \mathrm{ppm} \mathrm{Ag}^{+}$(blue), 100 ppm Au ${ }^{3+}$ mixed with

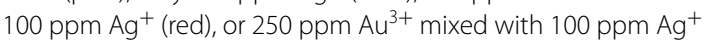
(green)

of Au@NPs were 108 ppm for SXM and 62 ppm for MR-1, respectively. It was found that an increase in biomass resulted in a decrease in Au@NPs. The presence of light dramatically accelerated nanoparticle formation. The mechanism of Au@NP formation and light-induced effect in Shewanella have been reported for the first time. The recovery of $\mathrm{Au}$ ions from industrial waste via Shewanella is a potential bioremediation option.

\section{Abbreviations}

Au@NPs: gold nanoparticles; Ag@NPs: silver nanoparticles; SXM: Shewanella xiamenensis BC01; MR-1: Shewanella oneidensis MR-1; SEM: scanning electron microscopy; ICP-OES: inductively coupled plasma-optical emission spectrometry.

\section{Authors' contributions}

ISN designed the experiment and analyzed the data, JWW performed most of experiments. ISN and JWW wrote the manuscript. Both authors read and approved the final manuscript.

\section{Acknowledgements}

The authors are grateful for the financial support for this study provided by the Ministry of Science and Technology (MOST 105-2221-E-006-225-MY3 and MOST-105-2621-M-006-012-MY3) in Taiwan.

\section{Competing interests}

The authors declare that they have no competing interests.

Availability of data and materials

The authors have agreed to provide the data and material for open access.

\section{Consent for publication}

The authors approved the consent for publishing the manuscript.

\section{Ethics approval and consent to participate}

All the authors have read and agreed the ethics for publishing the manuscript.

\section{Funding}

This work was supported by the Ministry of Science and Technology (MOST 105-2221-E-006-225-MY3 and MOST 105-2621-M-006-012-MY3) in Taiwan.

\section{Publisher's Note}

Springer Nature remains neutral with regard to jurisdictional claims in published maps and institutional affiliations.

Received: 24 August 2017 Accepted: 27 November 2017

Published online: 01 December 2017

\section{References}

Bai H, Zhang Z, Guo Y, Jia W (2009) Biological synthesis of size-controlled cadmium sulfide nanoparticles using immobilized Rhodobacter sphaeroides. Nanoscale Res Lett 4(7):717-723

Binupriya A, Sathishkumar M, Vijayaraghavan K, Yun SI (2010) Bioreduction of trivalent aurum to nano-crystalline gold particles by active and inactive cells and cell-free extract of Aspergillus oryzae var. viridis. J Hazard Mater 177(1):539-545

Chen T, Zhou Y, Ng IS, Yang CS, Wang HY (2015) Formation and characterization of extracellular polymeric substance from Shewanella xiamenensis BC01 under calcium stimulation. J Taiwan Inst Chem Eng 57:175-181

Coursolle D, Gralnick JA (2010) Modularity of the Mtr respiratory pathway of Shewanella ondeidensis strain MR-1. Mol Microbiol 77(4):995-1008

Dodson JR, Parker HL, Muñoz García A, Hicken A, Asemave K, Farmer TJ, He H, Clark JH, Hunt AJ (2015) Bio-derived materials as a green route for precious \& critical metal recovery and re-use. Green Chem 17(4):1951-1965

Farooq U, Kozinski JA, Khan MA, Athar M (2010) Biosorption of heavy metal ions using wheat based biosorbents-a review of the recent literature. Bioresour Technol 101(14):5043-5053

Fredrickson JK, Romine MF, Beliaev AS, Auchtung JM, Driscoll ME, Gardner TS, Nealson KH, Osterman AL, Pinchuk G, Reed JL, Rodionov DA, Rodrigues JLM, Saffarini DA, Serres MH, Spormann AM, Zhulin IB, Tiedje JM (2008) Towards environmental systems biology of Shewanella. Nat Rev Microbiol 6(8):592-603

He YR, Cheng YY, Wang WK, Yu HQ (2015) A green approach to recover Au(III) in aqueous solution using biologically assembled rGO hydrogels. Chem Eng J 270:476-484

Huang J, Sun B, Zhang X (2010) Shewanella xiamenensis sp. nov., isolated from coastal sea sediment. Int J Syst Evol Microbiol 60(7):1585-1589

Ishiki K, Okada K, Le DQ, Shiigi H, Nagaoka T (2017) Investigation concerning the formation process of gold nanoparticles by Shewanella oneidensis MR-1. Anal Sci 33(2):129-131

Kashefi K, Tor JM, Nevin KP, Lovley DR (2001) Reductive precipitation of gold by dissimilatory Fe(III)-reducing bacteria and archaea. Appl Environ Microbiol 67(7):3275-3279

Klaus T, Joerger R, Olsson E, Granqvist CG (2001) Bacteria as workers in the living factory: metal-accumulating bacteria and their potential for materials science. Trends Biotechnol 19(1):15-20 
Konishi Y, Ohno K, Saitoh N, Nomura T, Nagamine S, Hishida H, Takahashi Y, Uruga T (2007) Bioreductive deposition of platinum nanoparticles on the bacterium Shewanella algae. J Biotechnol 128(3):648-653

Kumar SA, Peter YA, Nadeau JL (2008) Facile biosynthesis, separation and conjugation of gold nanoparticles to doxorubicin. Nanotechnology 19(49):495101

Levskaya A, Chevalier AA, Tabor JJ, Simpson ZB, Lavery LA, Levy M, Davidson EA, Scouras A, Ellington AD, Marcotte EM, Voigt CA (2005) Synthetic biology: engineering Escherichia coli to see light. Nature 438(7067):441-442

Liu H, Logan BE (2004) Electricity generation using an air-cathode single chamber microbial fuel cell in the presence and absence of a proton exchange membrane. Environ Sci Technol 38(14):4040-4046

Liu DF, Min D, Cheng L, Zhang F, Li DB, Xiao X, Sheng GP, Yu HQ (2017) Anaerobic reduction of 2,6-dinitrotoluene by Shewanella oneidensis MR-1: roles of Mtr respiratory pathway and NfnB. Biotechnol Bioeng 114(4):761-768

Lo YC, Cheng CL, Han YL, Chen BY, Chang JS (2014) Recovery of high-value metals from geothermal sites by biosorption and bioaccumulation. Bioresour Technol 160:182-190

Mata YN, Torres E, Blazquez ML, Ballester A, Gonzalez F, Munoz JA (2009) Gold(III) biosorption and bioreduction with the brown alga Fucus vesiculosus. J Hazard Mater 166(2-3):612-618

Mishra A, Tripathy SK, Yun SI (2012) Fungus mediated synthesis of gold nanoparticles and their conjugation with genomic DNA isolated from Escherichia coli and Staphylococcus aureus. Process Biochem 47(5):701-711

Mishra A, Kumari M, Pandey S, Chaudhry V, Gupta KC, Nautiyal CS (2014) Biocatalytic and antimicrobial activities of gold nanoparticles synthesized by Trichoderma sp. Bioresour Technol 166:235-242

Myers CR, Nealson KH (1988) Bacterial manganese reduction and growth with manganese oxide as the sole electron acceptor. Science 240(4857):1319

Narayanan KB, Sakthivel N (2010) Biological synthesis of metal nanoparticles by microbes. Adv Colloid Interface Sci 156(1):1-13

Ng WO, Zentella R, Wang Y, Taylor AJS, Pakrasi BH (2000) PhrA, the major photoreactivating factor in the cyanobacterium Synechocystis sp. strain PCC 6803 codes for a cyclobutane-pyrimidine-dimer-specific DNA photolyase. Arch Microbiol 173:412-417

Ng CK, Sivakumar K, Liu X, Madhaiyan M, Ji L, Yang L, Tang C, Song H, Kjelleberg S, Cao B (2013) Influence of outer membrane c-type cytochromes on particle size and activity of extracellular nanoparticles produced by Shewanella oneidensis. Biotechnol Bioeng 110(7):1831-1837

Ng IS, Xu F, Zhang X, Ye C (2015a) Enzymatic exploration of catalase from a nanoparticle producing and biodecolorizing algae Shewanella xiamenensis BC01. Bioresour Technol 184:429-435

Ng IS, Ndive Cl, Zhou Y, Wu X (2015b) Cultural optimization and metal effects of Shewanella xiamenensis BC01 growth and swarming motility. Bioresour Bioprocess 2(1):28

Ramesh A, Hasegawa H, Sugimoto W, Maki T, Ueda K (2008) Adsorption of gold(III), platinum(IV) and palladium(II) onto glycine modified crosslinked chitosan resin. Bioresour Technol 99(9):3801-3809
Sancar A (2003) Structure and function of DNA photolyase and cryptochrome blue-light photoreceptors. Chem Rev 103:2203-2237

Sathishkumar M, Sneha K, Yun YS (2010a) Immobilization of silver nanoparticles synthesized using Curcuma longa tuber powder and extract on cotton cloth for bactericidal activity. Bioresour Technol 101(20):7958-7965

Sathishkumar M, Mahadevan A, Vijayaraghavan K, Pavagadhi S, Balasubramanian $\mathrm{R}$ (2010b) Green recovery of gold through biosorption, biocrystallization, and pyro-crystallization. Ind Eng Chem Res 49(16):7129-7135

Schmitz O, Katayama M, Williams BS, Kondo T, Golden SS (2000) CikA, a bacteriophytochrome that resets the cyanobacterial circadian clock. Science 289:765-768

Shedbalkar U, Singh R, Wadhwani S, Gaidhani S, Chopade BA (2014) Microbial synthesis of gold nanoparticles: current status and future prospects. Adv Colloid Interface Sci 209:40-48

Shi L, Rosso KM, Clarke TA, Richardson DJ, Zachara JM, Fredrickson JK (2012) Molecular underpinnings of Fe(III) oxide reduction by Shewanella oneidensis MR-1. Front Microbiol 3:50

Spitzer M, Bertazzoli R (2004) Selective electrochemical recovery of gold and silver from cyanide aqueous effluents using titanium and vitreous carbon cathodes. Hydrometallurgy 74(3):233-242

Suresh AK, Pelletier DA, Wang W, Broich ML, Moon JW, Gu B, Allison DP, Joy DC, Phelps TJ, Doktycz MJ (2011) Biofabrication of discrete spherical gold nanoparticles using the metal-reducing bacterium Shewanella oneidensis. Acta Biomater 7(5):2148-2152

Tan SI, Ng IS, Yu YY (2017) Heterologous expression of an acidophilic multicopper oxidase in Escherichia coli and its applications in biorecovery of gold. Bioresour Bioprocess 4:20

Wang G, Zhang B, Li S, Yang M, Yin C (2017) Simultaneous microbial reduction of vanadium(V) and chromium(VI) by Shewanella loihica PV-4. Bioresour Technol 227:353-358

Wu C, Cheng YY, Li BB, Li WW, Li DB, Yu HQ (2013a) Electron acceptor dependence of electron shuttle secretion and extracellular electron transfer by Shewanella oneidensis MR-1. Bioresour Technol 136:711-714

Wu R, Cui L, Chen L, Wang C, Cao C, Sheng G, Yu H, Zhao F (2013b) Effects of bio-Au nanoparticles on electrochemical activity of Shewanella oneidensis wild type and $\triangle$ omcA/mtrC mutant. Sci Rep 3:3307

Xu M, Guo J, Zeng G, Zhong X, Sun G (2006) Decolorization of anthraquinone dye by Shewanella decolorationis S12. Appl Microbiol Biotechnol $71(2): 246-251$

Yeh KC, Wu SH, Murphy JT, Lagarias JC (1997) A cyanobacterial phytochrome two-component light sensory system. Science 277:1505-1508

Zhu N, Cao Y, Shi C, Wu P, Ma H (2016) Biorecovery of gold as nanoparticles and its catalytic activities for p-nitrophenol degradation. Environ Sci Pollut Res Int 23(8):7627-7638

\section{Submit your manuscript to a SpringerOpen ${ }^{\circ}$ journal and benefit from:}

- Convenient online submission

- Rigorous peer review

- Open access: articles freely available online

- High visibility within the field

Retaining the copyright to your article

Submit your next manuscript at springeropen.com 